\title{
Appraisal of maize yield and its traits with different nitrogen fertilization levels under intercropping cultivation, Upper Egypt
}

\author{
Moghazy A. A. ${ }^{a^{*}}$, Youssef M. A. ${ }^{a}$, Dardiry M. R. ${ }^{b}$, Abdel-Mawgoud A. S. A. ${ }^{a}$ \\ ${ }^{a}$ Soils and Water Science Department, Faculty of Agriculture, Al-Azhar University (Assiut Branch), Assiut, Egypt \\ ${ }^{b}$ Water Requirements and Field Irrigation Department, Soil, Water and Environment Research Institute, Agriculture \\ Research Center, El-Mattaena Station, Luxor, Egypt
}

\begin{abstract}
A field experiment was conducted during summer season of 2017 and 2018 at the experimental farm of El-Mattaena Agricultural Research Station, Luxor Governorate, Upper Egypt, which is located at a $25^{\circ} 18^{-} \mathrm{N}$ latitude and $32^{\circ} 34^{-} \mathrm{E}$ longitude. The study aimed to evaluate the effect of nitrogen fertilizer levels on maize growth and its yield under sole and intercropping maize with green bean system as well as water productivity and saved land. The experiment was laid out in a split-plot design with four replicates. The main plots were assigned for two cropping system; (1) maize crop only and (2) maize intercropped with green bean. The split plots were occupied by urea fertilizer $(46.5 \% \mathrm{~N})$ levels of $90,120 \mathrm{and} 150 \mathrm{~kg}$ $\mathrm{N} /$ fed $($ fed $=$ feddan $=$ Acre). The maximum maize yield (grain and straw) and its component (plant height, stem diameter, leaves number/plant, grains number/cob and weight of 1000 grains) as well as NPK content in maize grain were observed under intercropping system that received $150 \mathrm{~kg} \mathrm{~N} / \mathrm{fed}$. The maximum value of partial land equivalent ratio (LER) of maize or green bean was recorded when they fertilized by $150 \mathrm{~kg} \mathrm{~N} / \mathrm{fed}$. The LERs of intercrops between maize and green bean showed that the saved lands were over $36 \%$. The highest values of crop water productivity of $1.40 \mathrm{~kg}$ grain $/ \mathrm{m}^{3}$ under intercropping system and $1.18 \mathrm{~kg}$ grain $/ \mathrm{m}^{3}$ under mono-cropping system were recorded with application of $150 \mathrm{~kg} \mathrm{~N} / \mathrm{fed}$. In general, fertilization at $150 \mathrm{~kg} \mathrm{~N} /$ fed. proved to be the most effective treatment for maize grain yield and its component as well as maize water relationships especially crop water productivity.
\end{abstract}

Keywords: nitrogen fertilization levels, intercropping system, land equivalent ratio, crop water productivity.

*Corresponding author: Moghazy A. A., 


\section{Introduction}

Nitrogen plays a pivotal role in several physiological processes inside the plants. Nitrogen also plays essential role in the growth and proper development of plant. Nitrogen is a component of protein and nucleic acids and when it becomes suboptimal, growth is reduced. Its availability in sufficient quantities throughout the growing season is essential for optimum crop growth. Nitrogen is the primary factor responsible for higher yield and for improving yield components of a certain crop. It affects various physiological and biochemical processes in plant cells (Ciampitti and Vyn, 2010). Leila and Soleymani (2014) indicated that the rows number /ear, seed number /row, grains number /cop, seed weight and seed yield were significantly affected by nitrogen fertilization and cultivar. Kaur et al. (2015) found that the leaves number /plant was 13.9 with $150 \mathrm{~kg} \mathrm{~N} \mathrm{ha}^{-1}$ and 12.3 with no $\mathrm{N}$ application. Imran et al. (2015) found that application of nitrogen at rate of $210 \mathrm{~kg} \mathrm{~N}$ ha $^{-1}$ produced maximum leaf area index (LAI) of 2.76 which is statistically equal to 180 and 150 $\mathrm{kg} \mathrm{N} \mathrm{ha}{ }^{-1}$ with the LAI of 2.54 and 2.52, respectively. Kaurr (2016) found that increase nitrogen levels to $180 \mathrm{~kg} \mathrm{~N}^{-1}$ produced significantly taller plants of $218.3 \mathrm{~cm}$ compared to $150 \mathrm{~kg} \mathrm{~N} \mathrm{ha}^{-1}$ that produced plants height of $215 \mathrm{~cm}$. Woldesenbet and Haileyesus (2016) indicated that the effects of different rates of $\mathrm{N}$ fertilizer had influenced the growth and yield components of maize. The tallest plant $(360.66 \mathrm{~cm})$ was recorded from the application of $92 \mathrm{~kg} \mathrm{~N} \mathrm{ha}^{-1}$ and the shortest one $(347.33 \mathrm{~cm})$ without $\mathrm{N}$ application. Nawab et al. (2017) recorded maximum plant height $(171.0 \mathrm{~cm})$, stem diameter $(3.68 \mathrm{~cm})$ with application nitrogen levels of $180 \mathrm{~kg} \mathrm{~N}^{-1}$ over those of $130,160 \mathrm{~kg} \mathrm{~N}^{-1}{ }^{-1}$. Zulfiqar et al. (2017) observed that application of 175 $\mathrm{kg} \mathrm{N} \mathrm{ha}^{-1}$ produced maximum plant height $(165.35 \mathrm{~cm})$, which were significantly higher than that of 100 and $125 \mathrm{~kg} \mathrm{~N} \mathrm{ha}^{-1}(137.90 \mathrm{~cm})$. Shrestha et al. (2018) found that the application of nitrogen up to $200 \mathrm{~kg} \mathrm{~N} / \mathrm{ha}$ increased the growth traits. Badwal et al. (2019) found that the rate of nitrogen fertilizer application mainly influence the growth and development yield of the crop. Growth attributes like leaves number /plant, dry matter accumulation, LAI vary with rate of applied nitrogen. Maize crop (Zea mays) is ranked the third important crop after wheat and rice in many countries all over the world. Maize (Zea mays L.) is the principal summer cereal crop grown by many farmers in either mixed or sole cropping system and is also a priority crop to farmers because it is the staple food in many rural communities of Egypt. Its production is declining due to limited water, pest attack, declining soil fertility caused by continuous monocropping of maize and inadequate fertilization of crops. Maize is desired for its multiple purposes as human food, animal feed, and pharmaceutical and industrial manufacturing. Most of the maize is grown as intercrops with grain legumes (Moriri et al., 2010). Intercropping system is generally more productive than single crop and also, could be a method for irrigation water saving, increased $\mathrm{N}$ and $\mathrm{P}$ availability, and positively affected the 
microbiological activity in rhizosphere of the crop species compared to single cropping. Moreover intercropping system aimed to adopt improved and sustainable technologies in order to guarantee improvements in food productivity and thereby food security (Coll et al., 2012; Ijoyah and Fanen, 2012). Intercropping of cereal-legume cultivation is the most common practiced crop. Nitrogen fixing legumes such as cowpea, pigeon pea, common bean, soybean, French bean, can be included to a greater extent in arable cropping systems via intercrops. Legumes contribute to maintaining the soil fertility via $\mathrm{N}$ fixation, which is increased in intercrops due to the more competitive character of the cereal for soil inorganic $\mathrm{N}$. This leads to a complementary and more efficient use of $\mathrm{N}$ sources by the crops in the intercrop system (Nyasasi and Kisetu, 2014). Mateusso et al. (2014) observed that maize-soybean intercropping patterns had significant effect on maize stover and grain yields during both growing seasons. Heidari et al. (2015) showed that intercropping systems had significant effects on biological yield of maize and green bean, dry weight of green bean sheath, corn dry weight, ear length and ear diameter. Latati et al. (2016) stated that common bean improves soil fertility through fixation of atmospheric $\mathrm{N}_{2}$ in symbiosis with rhizobia. Almaz et al. (2017) found that the higher land equivalent ratio (LER) of 1.53 was noticed in simultaneous sowing of maize + fodder cowpea (1:2) over all other intercropping treatments. Nassary et al. (2020) found that the LER for maize intercropped with local beans were 1.48 and 1.55 , respectively but LER values did not differ significantly between bean varieties. The objective of this study is to determine the effect of nitrogen fertilization levels on the yield of maize grown alone or under intercropping maize-green bean systems and intercropping efficiency as well as crop water productivity.

\section{Materials and methods}

A field experiment was conducted during summer seasons of 2017 and 2018 at the experimental farm of El-Mattaena Agricultural Research Station, Luxor Governorate, Upper Egypt, which is located at a 250 18/ N latitude, 32o 34/ E longitude and at altitude about $82 \mathrm{~m}$ above mean sea level. The experiment was laid out in a split-plot design with four replicates. The main plots were assigned for two cropping system one for maize crop alone and the second for intercropping maize with green bean. The split plots were occupied by urea fertilizer $(46.5 \% \mathrm{~N})$ levels of 90,120 and $150 \mathrm{~kg} \mathrm{~N} / \mathrm{fed}(\mathrm{fed}=$ feddan $=$ Acre $)$ named as N90, N120 and N150, respectively. All the experimental treatments were randomly distributed on the respective plots. The plot was $7 \mathrm{~m}$ in length and $3 \mathrm{~m}$ in width with an area of $21 \mathrm{~m} 2$. Soil samples were performed before and after each growing season to $60 \mathrm{~cm}$ soil depth with $15 \mathrm{~cm}$ increment by using a spiral auger. The samples were air dried ground and sieved through $2 \mathrm{~mm}$ sieve and prepared for chemical 
and physical analysis according to Page relevant physical and chemical properties et al. (1982) and Klute (1986). The are shown in Table (1).

Table (1): Some chemical properties (for $30 \mathrm{~cm}$ soil layer) and bulk density (of 4 soil depths) of the experimental site during the growing season of 2017 and 2018.

\begin{tabular}{|c|c|c|c|c|c|c|c|}
\hline Chemical properties & 2017 & 2018 & \multicolumn{5}{|c|}{ Physical properties } \\
\hline Soil pH (1: 2.5) & 7.74 & 7.36 & \multirow{2}{*}{ Parameters } & \multirow{2}{*}{\multicolumn{2}{|c|}{2017}} & \multirow{2}{*}{\multicolumn{2}{|c|}{2018}} \\
\hline EC 1: $2.5(\mathrm{dS} / \mathrm{m})$ & 0.51 & 0.67 & & & & & \\
\hline \multirow{2}{*}{$\begin{array}{l}\text { Soluble ions (meq./ L) } \\
\mathrm{CO}_{3} \\
\mathrm{HCO}_{3} \\
\mathrm{Cl} \\
\mathrm{SO}_{4} \\
\mathrm{Ca} \\
\mathrm{Mg} \\
\mathrm{Na} \\
\mathrm{K}\end{array}$} & \multirow{2}{*}{$\begin{array}{c}0.00 \\
14.75 \\
7.00 \\
22.00 \\
21.50 \\
12.00 \\
8.50 \\
2.50\end{array}$} & \multirow{2}{*}{$\begin{array}{c}0.00 \\
11.75 \\
10.50 \\
22.75 \\
23.00 \\
8.50 \\
12.50 \\
2.25\end{array}$} & $\begin{array}{l}\text { SP } \\
\mathrm{OM} \mathrm{\%} \\
\mathrm{CaCO}_{3} \% \\
\text { Sand \% } \\
\text { Silt \% } \\
\text { Clay \% } \\
\text { Texture class }\end{array}$ & \multicolumn{2}{|c|}{$\begin{array}{c}59 \\
1.83 \\
3.50 \\
34.34 \\
29.60 \\
36.06 \\
\text { Clay loam }\end{array}$} & \multicolumn{2}{|c|}{$\begin{array}{c}60 \\
1.10 \\
3.70 \\
34.31 \\
28.90 \\
35.99 \\
\text { Clay loam }\end{array}$} \\
\hline & & & \multicolumn{5}{|c|}{ Soil depth $(\mathrm{cm})$} \\
\hline \multirow{2}{*}{$\begin{array}{cc} & \mathrm{N} \\
\text { Available (ppm) } & \mathrm{P} \\
& \mathrm{K}\end{array}$} & $\begin{array}{l}45.00 \\
2000\end{array}$ & $\begin{array}{l}43.00 \\
21.20\end{array}$ & \multirow{3}{*}{$\begin{array}{c}\text { Bulk density } \\
\left(\mathrm{g} / \mathrm{cm}^{3}\right)\end{array}$} & $0-15$ & $15-30$ & $30-45$ & $45-60$ \\
\hline & 69.00 & 71.00 & & 1.09 & 1.21 & 1.26 & 1.28 \\
\hline CEC (meq./L) & 38.52 & 39.08 & & & & & \\
\hline
\end{tabular}

$\mathrm{SP}=$ saturation percentage, $\mathrm{OM}=$ organic matter.

Maize (Zea mays L.) cv. Giza 168, was planted on July $5^{\text {th }}$ of both growing seasons (2017 and 2018), and over seeded on raised beds at a double rate and then thinned by hand after emergence to attain the desired plant densities with $25 \mathrm{~cm}$ away among plants. Maize plants were harvested on $22^{\text {nd }}$ and $19^{\text {th }}$ of Oct. 2017 and 2018 growing seasons at age 109 and 106 days, respectively. Green bean seeds (Giza 6) were planted in the mid bed after the first irrigation of maize plants. Phosphorus fertilizer in the form of supper phosphate $\left(15.5 \% \mathrm{P}_{2} \mathrm{O}_{5}\right)$ at a rate of $200 \mathrm{~kg} / \mathrm{fed}$ was added during soil preparation. Nitrogen fertilizer was applied in the form of urea $(46.5 \% \mathrm{~N})$ at three rates of 90,120 and $150 \mathrm{~kg} \mathrm{~N} / \mathrm{fed}$ which is divided into two equal doses. The first dose was added before the first irrigation. While the second one in addition to potassium (potassium sulphate $48 \% \mathrm{~K}_{2} \mathrm{O}$ ) at a rate of $50 \mathrm{~kg} \mathrm{~K} / \mathrm{fed}$ was applied before the second irrigation. All the agronomic practices were carried out according to the recommendation of the Ministry of Agriculture, Egypt. To obtain the actual evapotranspiration $\left(\mathrm{ET}_{\mathrm{a}}\right)$, the soil moisture percentage was determined gravimetrically on dry basis just before and 48 hours after irrigation as well as at harvesting time. At each sampling date, samples were taken from four layers each of $15 \mathrm{~cm}$ depth from soil surface down to $60 \mathrm{~cm}$. The amount of water consumed $\left(\mathrm{ET}_{\mathrm{a}}\right)$ from the root zone between two successive irrigations as water depth in 
$\mathrm{cm}$, was calculated according to Israelsen and Hansen (1962) using the following equation:

$\mathrm{ET}_{\mathrm{a}}=\left\{\left(\theta_{2}-\theta_{1}\right) / 100\right\} \times \mathrm{Bd} \times \mathrm{D} / 100 \times 4200$

Where: $\mathrm{ET}_{\mathrm{a}}=$ actual evapotranspiration $\left(\mathrm{m}^{3}\right) . \quad \theta_{2}=$ soil moisture $(\%)$ after irrigation. $\theta_{1}=$ soil moisture (\%) before irrigation. $\mathrm{Bd}=$ soil bulk density $\left(\mathrm{g} / \mathrm{cm}^{3}\right)$. $\mathrm{D}=$ soil depth $(\mathrm{cm})$.

Crop water productivity (CWP) was calculated according to Vites (1965) using the following equations:

$\mathrm{CWP}=$ grain yield $(\mathrm{kg} / \mathrm{fed}) /$ Seasonal $\mathrm{ET}_{\mathrm{a}}\left(\mathrm{m}^{3} / \mathrm{fed}\right)$

Ten guarded plants were chosen from each experimental plot and labeled. Thus, the following characteristics parameters were recorded at harvesting time:

○ Plant height $(\mathrm{cm})$.

- Leaves number/plant.

- Stem diameter $(\mathrm{cm})$.

- Grains number /cob.

- 1000-grains weight (g).

- Grain yield was determined using the centric area of each plot $1.5 \mathrm{~m} \times 7 \mathrm{~m}=$ $10.5 \mathrm{~m}^{2}$. After shelling, the grains of each plot were weighted and the average grain yield (ton /fed) was calculated at $15.5 \%$ moisture.

- Straw yield was determined by subtracting biological yield (ton/ fed) from the grain weight (ton /fed) for each plot.

Samples of maize grains form every experiment unit was collected, dried and milled. The milled samples were wet digested according to Thomas et al. (1967). The NPK content of maize grains was determined as mentioned by FAO (1980). The partial (individual crop's) land equivalent ratio (LER) and the total LER were determined according to Mead and Riley (1981) as follows:

LER $=$ PLER $_{\text {maize }}+$ PLER $_{\text {green bean }}$

PLER maize $=$ Maize yield in intercrop/ Maize yield in monoculture

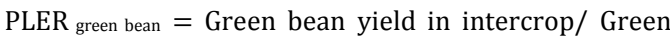
bean yield in monoculture

Where: PLER is the partial land equivalent ratio of maize or green bean.

Land saved was calculated using the equation proposed by Willey (1985) as follows:

Land saved $\%=(100-1 /$ LER $) \times 100$

The obtained data were analyzed using the statistical package of MSTAT-C according to Nissen (1989). The mean values of each treatment were compared using the Least Significant Differences (LSD) at probability level of 0.05 .

\section{Results and Discussion}

The intercrop is generally practiced to make best use of interspace which is not fully utilized by main crop in early growth periods. The intercrop may reduce or increase the yield of main crop, depending upon the species and spatial arrangement of component crops.

\subsection{Maize growth components}

Data presented in Table (2) shows the effect of nitrogen fertilization levels on 
maize traits under sole and intercropping system during growing seasons of 2017 and 2018. In general, the results indicated that maize plants height was increased as nitrogen fertilization levels increased and under intercropping system compared to mono-cropping system during both seasons. It varied from 238.8 to $252.4 \mathrm{~cm}$ when nitrogen fertilization increased from 90 to $150 \mathrm{~kg} \mathrm{~N} /$ fed under intercropping system and it differed from 236.8 to $251.0 \mathrm{~cm}$ for the corresponding treatments under mono-cropping system in the $1^{\text {st }}$ season. The same trend was found in the $2^{\text {nd }}$ season. On average basis, the plant height increased by 0.8 and $1.12 \%$ in the $1^{\text {st }}$ and $2^{\text {nd }}$ season, respectively (Table 2). The obtained results are in agreement with those obtained by Sadeghi and Kazemeini (2012) whom revealed that increasing the nitrogen fertilizer level increased leaf area, plant height and dry weight of maize under different maize-bean intercropping patterns.

\subsubsection{Leaves number/plant}

Leaves number/plant was increased as nitrogen fertilization levels increased and under intercropping system compared to mono-cropping system during both seasons. It varied from 15.50 to 16.50 when nitrogen fertilization increased from 90 to $150 \mathrm{~kg}$ N/fed under intercropping system and it differed from 15.0 to 16.20 for the corresponding treatments under mono-cropping system in the $1^{\text {st }}$ season. The same trend was realized in the $2^{\text {nd }}$ season. On average basis, the leaves number/plant was increased by 2.58 and $4.87 \%$ in the $1^{\text {st }}$ and $2^{\text {nd }}$ season, respectively (Table 2 ). These results are in harmony with those obtained by Adesoji et al. (2013) whom revealed that the increase in maize growth might be as a result of nitrogen effects that lead to increase cell division, cell expansion and increase in size of all its morphological parts (e.g. leaves number/plant). Stem diameter increased as nitrogen fertilization levels increased and under intercropping system compared to mono-cropping system during both seasons. It varied from 3.20 to $3.70 \mathrm{~cm}$ when nitrogen fertilization increased from 90 to $150 \mathrm{~kg} \mathrm{~N} /$ fed under intercropping system and it differed from 3.10 to $3.60 \mathrm{~cm}$ for the corresponding treatments under mono-cropping system in the $1^{\text {st }}$ season. The same trend was realized in the $2^{\text {nd }}$ season. On average basis, the stem diameter increased by 4.02 and $2.83 \%$ in the $1^{\text {st }}$ and $2^{\text {nd }}$ season, respectively (Table 2). This result is in accordance with that of Sabiel (2007) who reported that there was positive and significant correlation between stem diameter and plant height. Carpici et al. (2010) reported that response of stem diameter to $\mathrm{N}$ fertilization was statistically significant. They further indicated that stem diameter increased up to $300 \mathrm{~kg} \mathrm{~N} \mathrm{ha}^{-1}$ and then stayed stable at $400 \mathrm{~kg} \mathrm{ha}^{-1}$. Widowati et al. (2012) found that nitrogen application improves plant growth by increasing plant height and stem diameter at the end of vegetative 
growth. Sebetha (2015) found that Grain number /cob was increased as nitrogen fertilizer application had nitrogen fertilization levels increased and significant effect on maize stem diameter. Maize applied with $\mathrm{N}$ fertilizer had significantly large stem diameter of $2.0 \mathrm{~cm}$ than maize without $\mathrm{N}$ fertilizer application. Maize planted during 2011/12 planting season had significantly large stem diameter of $1.9 \mathrm{~cm}$ than maize planted during 2012/13 planting season. Maize stem diameter was significantly affected by the interaction of site $\mathrm{x}$ nitrogen and cropping system $x$ season.

\subsubsection{The grain number /cob}

under intercropping system compared to mono-cropping system during both seasons. It varied from 504.20 to 690.30 when nitrogen fertilization increased from 90 to $150 \mathrm{~kg}$ N/fed under intercropping system and it differed from 459.50 to 569.10 for the corresponding treatments under mono-cropping system in the $1^{\text {st }}$ season. The same trend was realized in the $2^{\text {nd }}$ season. On average basis, the grain number /cob was increased by 13.07 and $4.49 \%$ in the $1^{\text {st }}$ and $2^{\text {nd }}$ season, respectively (Table 2).

Table (2): The effect of nitrogen fertilization levels on maize traits under both solely and intercropping system during the growing seasons of 2017 and 2018.

\begin{tabular}{|c|c|c|c|c|c|c|c|c|c|c|}
\hline \multirow{3}{*}{ Maize trait } & \multirow{3}{*}{\multicolumn{2}{|c|}{ Cultivation system }} & \multicolumn{8}{|c|}{ Nitrogen $(\mathrm{kg} / \mathrm{fed})$} \\
\hline & & & & & & & & & $\overline{18}$ & \\
\hline & & & 90 & 120 & 150 & Average & 90 & 120 & 150 & Average \\
\hline \multirow{3}{*}{ Plant height $(\mathrm{cm})$} & \multicolumn{2}{|c|}{ Inter. } & 238.80 & 245.20 & 252.40 & 245.47 & 239.50 & 247.70 & 257.00 & 248.07 \\
\hline & \multicolumn{2}{|c|}{ Sole } & 236.80 & 242.80 & 251.00 & 243.53 & 236.30 & 245.70 & 254.00 & 245.33 \\
\hline & \multicolumn{2}{|c|}{ R.C. } & 0.84 & 0.99 & 0.56 & 0.80 & 1.35 & 0.81 & 1.18 & 1.12 \\
\hline \multirow{3}{*}{ Leaves number/plant } & \multicolumn{2}{|c|}{ Inter. } & 15.50 & 16.00 & 16.50 & 16.00 & 15.90 & 15.70 & 16.60 & 16.07 \\
\hline & \multirow{2}{*}{\multicolumn{2}{|c|}{$\begin{array}{l}\text { Sole } \\
\text { R.C. }\end{array}$}} & 15.00 & 15.60 & 16.20 & 15.60 & 14.70 & 15.10 & 16.20 & 15.33 \\
\hline & & & 3.33 & 2.56 & 1.85 & 2.58 & 8.16 & 3.97 & 2.47 & 4.87 \\
\hline \multirow{3}{*}{ Stem diameter $(\mathrm{cm})$} & \multicolumn{2}{|c|}{ Inter. } & 3.20 & 3.50 & 3.70 & 3.47 & 3.20 & 3.50 & 3.80 & 3.50 \\
\hline & \multirow{2}{*}{\multicolumn{2}{|c|}{$\begin{array}{l}\text { Sole } \\
\text { R.C. }\end{array}$}} & 3.10 & 3.30 & 3.60 & 3.33 & 3.20 & 3.40 & 3.60 & 3.40 \\
\hline & & & 3.23 & 6.06 & 2.78 & 4.02 & 0.00 & 2.94 & 5.56 & 2.83 \\
\hline \multirow{3}{*}{ Grain number /cob } & \multicolumn{2}{|c|}{ Inter. } & 504.20 & 566.00 & 690.30 & 586.83 & 524.20 & 621.70 & 691.50 & 612.47 \\
\hline & \multirow{2}{*}{\multicolumn{2}{|c|}{$\begin{array}{l}\text { Sole } \\
\text { R.C. }\end{array}$}} & 459.50 & 523.20 & 569.10 & 517.27 & 518.30 & 587.50 & 649.20 & 585.00 \\
\hline & & & 9.73 & 8.18 & 21.30 & 13.07 & 1.14 & 5.82 & 6.52 & 4.49 \\
\hline \multirow{3}{*}{$\begin{array}{l}\text { 1000-grains weight } \\
\text { (g) }\end{array}$} & \multicolumn{2}{|c|}{ Inter. } & 313.80 & 328.80 & 346.30 & 329.63 & 310.00 & 326.70 & 348.30 & 328.33 \\
\hline & \multirow{2}{*}{\multicolumn{2}{|c|}{$\begin{array}{l}\text { Sole } \\
\text { R.C. }\end{array}$}} & 310.70 & 325.00 & 343.00 & 326.23 & 304.70 & 324.70 & 344.00 & 324.47 \\
\hline & & & 1.00 & 1.17 & 0.96 & 1.04 & 1.74 & 0.62 & 1.25 & 1.20 \\
\hline \multirow{2}{*}{ Maize trait } & \multicolumn{2}{|c|}{ Plant height } & \multicolumn{2}{|c|}{ Leaves No. plant } & \multicolumn{2}{|c|}{ Stem diameter } & \multicolumn{2}{|c|}{ Grain No. } & \multicolumn{2}{|c|}{1000 -grains weight } \\
\hline & 2017 & 2018 & 2017 & 2018 & 2017 & 2018 & 2017 & 2018 & 2017 & 2018 \\
\hline \multirow{3}{*}{$\begin{array}{ll} & \text { Inter. } \\
\text { LSD }_{(0.05)} & \mathrm{N} \\
& \text { Inter. X N } \\
\end{array}$} & 0.9 & 0.63 & 0.21 & 0.23 & 0.02 & 0.03 & 16.68 & 12.6 & 1.2 & 1.49 \\
\hline & 1.7 & 0.52 & 0.14 & 0.2 & 0.02 & 0.09 & 13.65 & 8.4 & 1.63 & 1.72 \\
\hline & NS & NS & NS & NS & NS & NS & NS & NS & NS & NS \\
\hline
\end{tabular}

Inter. = Intercropping, R.C. $=$ Relative change, $\mathrm{N}=$ Nitrogen fertilizer levels (kg N/fed).

The results are compatible with those obtained by Gadallah and Gabra (2015) whom reported that, plant height, ear diameter, ear length, number of grains/row, ear grains weight and grain yield per fad of maize were increased by increasing nitrogen fertilizer levels from 90 to $120 \mathrm{~kg} \mathrm{~N} / \mathrm{fed}$. 


\subsubsection{0-grains weight}

The weight of 1000 grains increased as nitrogen fertilization levels increased and under intercropping system compared to mono-cropping system during both seasons. It varied from 313.80 to 346.30 $\mathrm{g}$ when nitrogen fertilization increased from 90 to $150 \mathrm{~kg} \mathrm{~N} /$ fed under intercropping system and it differed from 310.70 to $343.00 \mathrm{~g}$ for the corresponding treatments under mono-cropping system in the $1^{\text {st }}$ season. The same trend was realized in the $2^{\text {nd }}$ season. On average basis, the weight of 1000 grains increased by 1.04 and $1.20 \%$ in the $1^{\text {st }}$ and $2^{\text {nd }}$ season, respectively (Table 2 ). The result is in agreement of that obtained by Kumar et al. (2008) whom reported that growth parameters and yield attributes, grain yield, maize grain equivalent yield and total $\mathrm{N}$ uptake by maize increased significantly with increasing $\mathrm{N}$ rate in combination with plant growth promoting rhizobacteria (PGPR) + organic manure. Saleem et al. (2011) observed significant increase in 1000-grain weight (249.42 g) when plot was treated with half poultry manure+ half $\mathrm{PK}+$ inoculation with PGPR followed by NPK application with an average grain weight of $(243.39 \mathrm{~g})$ in all cropping systems. Also, they stated that grain yield was linearly increased with the increase in 1000-grain weight.

\subsection{Maize yield and quality}

Data presented in Table (3) shows the effect of nitrogen fertilization levels on maize yield and its quality under sole and intercropping system during growing season of 2017 and 2018. In general, the results indicated that maize grain yield increased as nitrogen fertilization levels increased and under intercropping system compared to mono-cropping system during both seasons. It varied from 2.36 to 3.09 ton /fed when nitrogen fertilization increased from 90 to $150 \mathrm{~kg}$ $\mathrm{N} /$ fed under intercropping system and it differed from 2.27 to 2.95 ton /fed for the corresponding treatments under monocropping system in the $1^{\text {st }}$ season. The same trend was realized in the $2^{\text {nd }}$ season since the grain yield increased from 2.72 to $3.26 \mathrm{ton} / \mathrm{fed}$ and from 2.60 to 3.13 ton/fed under inter and mono-cropping system, respectively for the corresponding treatments in the $2^{\text {nd }}$ season. On average basis, the grain yield increased by 4.03 and $4.57 \%$ in the $1^{\text {st }}$ and $2^{\text {nd }}$ season, respectively (Table 3 ). The obtained results are in agreement with those obtained by Tsubo et al. (2005) whom stated that legume-cereal intercropping is generally more productive than mono-crop. Since when two crops are grown together yield advantages occurs because of differences in their use of resources. Thayamini and Brintha (2010) noted that the planting pattern of maize and legume did not affect the maize yield. Also, Fathi (2014) concluded that nitrogen fertilizer application significantly increased the grain yields and above-ground biomass of maize at all rates of nitrogen 
application (30,60 and $120 \mathrm{~kg} / \mathrm{fed})$ and the highest grain yield was recorded in maize + soybean intercropping with entire recommended rate of mineral nitrogen application.

\subsubsection{The maize straw yield}

Maize straw yield increased as nitrogen fertilization levels increased and under intercropping system compared to monocropping system during both seasons. It varied from 5.47 to 6.13 ton /fed when nitrogen fertilization increased from 90 , 120 and $150 \mathrm{~kg} \quad \mathrm{~N} / \mathrm{fed}$ under intercropping system and it differed from 5.35 to 6.02 ton/fed for the corresponding treatments under monocropping system in the $1^{\text {st }}$ season. The same trend was realized in the $2^{\text {nd }}$ season since the straw yield increased from 5.68 to 6.26 ton/fed. and from 5.50 to 6.10 ton/fed. under inter and mono-cropping system, respectively for the corresponding treatments in the $2^{\text {nd }}$ season. On average basis, intercropping the straw yield increased by 2.13 and $2.30 \%$ in the $1^{\text {st }}$ and $2^{\text {nd }}$ season, respectively (Table 3 ). The obtained results are in agreement with those obtained by Nawab et al. (2017) whom found that the highest values of biological yields, grain yields, straw yields, ear lengths, grains numbers /row, rows numbers /ear, grains numbers /ear and weight of 1000-grains were obtained at $180 \mathrm{~kg} \mathrm{~N} \mathrm{ha}^{-1}$ compared to those at 130 or $160 \mathrm{~kg} \mathrm{~N} \mathrm{ha}^{-1}$.

Table (3): The effect of nitrogen fertilization levels on maize grain and straw yield and its quality under both solely and intercropping systems during the growing seasons of 2017 and 2018 .

\begin{tabular}{|c|c|c|c|c|c|c|c|c|c|c|}
\hline \multirow{3}{*}{$\begin{array}{l}\text { Maize yield and } \\
\text { quality }\end{array}$} & \multirow{3}{*}{\multicolumn{2}{|c|}{ Cultivation system }} & \multicolumn{8}{|c|}{ Nitrogen $(\mathrm{kg} / \mathrm{fed})$} \\
\hline & & & \multicolumn{4}{|c|}{2017} & \multicolumn{4}{|c|}{2018} \\
\hline & & & 90 & 120 & 150 & Average & 90 & 120 & 150 & Average \\
\hline \multirow{3}{*}{ Grain (ton /fed) } & \multicolumn{2}{|c|}{ Inter. } & 2.36 & 2.75 & 3.09 & 2.73 & 2.72 & 2.97 & 3.26 & 2.98 \\
\hline & \multicolumn{2}{|c|}{ Sole } & 2.27 & 2.66 & 2.95 & 2.63 & 2.60 & 2.83 & 3.13 & 2.85 \\
\hline & \multicolumn{2}{|c|}{ R.C. } & 3.96 & 3.38 & 4.75 & 4.03 & 4.62 & 4.95 & 4.15 & 4.57 \\
\hline \multirow{3}{*}{ Straw (ton /fed) } & \multicolumn{2}{|c|}{ Inter. } & 5.47 & 5.75 & 6.13 & 5.78 & 5.68 & 5.98 & 6.26 & 5.97 \\
\hline & \multicolumn{2}{|c|}{ Sole } & 5.35 & 5.62 & 6.02 & 5.66 & 5.50 & 5.92 & 6.10 & 5.84 \\
\hline & \multicolumn{2}{|c|}{ R.C. } & 2.24 & 2.31 & 1.83 & 2.13 & 3.27 & 1.01 & 2.62 & 2.30 \\
\hline \multirow{3}{*}{ Grain N-content $(\%)$} & \multicolumn{2}{|c|}{ Inter. } & 1.32 & 1.47 & 1.52 & 1.44 & 1.37 & 1.43 & 1.50 & 1.43 \\
\hline & \multicolumn{2}{|c|}{ Sole } & 1.28 & 1.44 & 1.48 & 1.40 & 1.33 & 1.40 & 1.46 & 1.40 \\
\hline & \multicolumn{2}{|c|}{ R.C. } & 3.13 & 2.08 & 2.70 & 2.64 & 3.01 & 2.14 & 2.74 & 2.63 \\
\hline \multirow{3}{*}{ Grain P-content (\%) } & \multicolumn{2}{|c|}{ Inter. } & 0.40 & 0.45 & 0.54 & 0.46 & 0.59 & 0.70 & 0.78 & 0.69 \\
\hline & \multirow{2}{*}{\multicolumn{2}{|c|}{$\begin{array}{l}\text { Sole } \\
\text { R.C. }\end{array}$}} & 0.37 & 0.41 & 0.46 & 0.41 & 0.46 & 0.65 & 0.74 & 0.62 \\
\hline & & & 8.11 & 9.76 & 17.39 & 11.75 & 28.26 & 7.69 & 5.41 & 13.79 \\
\hline \multirow{3}{*}{ Grain K-content $(\%)$} & \multicolumn{2}{|c|}{ Inter. } & 0.62 & 0.64 & 0.74 & 0.67 & 0.72 & 0.77 & 0.84 & 0.78 \\
\hline & \multicolumn{2}{|c|}{ Sole } & 0.56 & 0.62 & 0.67 & 0.62 & 0.66 & 0.71 & 0.75 & 0.71 \\
\hline & \multicolumn{2}{|c|}{ R.C. } & 10.71 & 3.23 & 10.45 & 8.13 & 9.09 & 8.45 & 12.00 & 9.85 \\
\hline \multirow{2}{*}{$\begin{array}{l}\text { Maize yield and } \\
\text { quality }\end{array}$} & \multicolumn{2}{|c|}{ Grain $_{\text {(ton/ fed) }}$} & \multicolumn{2}{|c|}{ Straw $_{\text {(ton/ fed) }}$} & \multicolumn{2}{|c|}{ Grain N-content } & \multicolumn{2}{|c|}{ Grain P-content } & \multicolumn{2}{|c|}{ Grain K-content } \\
\hline & 2017 & 2018 & 2017 & 2018 & 2017 & 2018 & 2017 & 2018 & 2017 & 2018 \\
\hline \multirow{3}{*}{$\begin{array}{ll} & \text { Inter. } \\
\text { LSD }_{(0.05)} & \mathrm{N} \\
& \text { Inter. X N }\end{array}$} & 0.02 & 0.04 & 0.04 & 0.04 & 0.02 & 0.03 & 0.08 & 0.02 & 0.03 & 0.04 \\
\hline & 0.03 & 0.03 & 0.03 & 0.03 & 0.02 & 0.02 & NS & 0.04 & 0.04 & 0.03 \\
\hline & NS & NS & NS & 0.05 & NS & NS & NS & NS & NS & NS \\
\hline
\end{tabular}

Inter. = Intercropping, R.C. = Relative change, $\mathrm{N}=$ Nitrogen fertilizer levels $(\mathrm{kg} \mathrm{N} / \mathrm{fed})$. 


\subsubsection{The grain nitrogen content}

Grain nitrogen content increased as nitrogen fertilization levels increased and under intercropping system compared to mono-cropping system during both seasons. The increase varied from 1.32 to $1.52 \%$ when nitrogen fertilization increased from 90 to $150 \mathrm{~kg} \mathrm{~N} / \mathrm{fed}$ under intercropping system and it differed from 1.28 to $1.48 \%$ for the corresponding treatments under mono-cropping system in the $1^{\text {st }}$ season. The same trend was realized in the $2^{\text {nd }}$ season since the grain nitrogen content increased from 1.37 to $1.50 \%$ and from 1.33 to $1.46 \%$ under inter and mono-cropping system, respectively for the corresponding treatments in the $2^{\text {nd }}$ season. On average basis, the grain nitrogen content increased by 2.64 and $2.63 \%$ in the $1^{\text {st }}$ and $2^{\text {nd }}$ season, respectively (Table 3 ). These findings agreed with those of Akunda (2004) who reported that using legumes in intercropping and in biological nitrogen fixing, nitrogen fertilizer consumption is reduced and its effect is preventing the environmental pollution. Nitrogen uptake by intercropping of wheat and maize was greater than that by corresponding sole cropping under same supply (Singh and Agrawal, 2004). Adu-Gyamfi et al. (2007) stated that cereal-legume mixtures have been adjudged the most productive form of intercropping since the cereals may benefit from the nitrogen fixed in the root nodules of the legumes in the current cropping year. In this regard, there is a possibility of root exudates or the decay of roots and nodules causing the release of $\mathrm{N}$ from legumes into the rhizosphere during the cropping season. Ananthi et al. (2017) revealed that cereal-legume intercropping is a more productive and profitable cropping system in comparison with solitary cropping. Maize-legume intercropping systems are able to lessen amount of nutrients taken from the soil in comparison to maize. Moreover, intercropping improves soil fertility through atmospheric nitrogen fixation from atmosphere (150 tons /year) with the use of legumes, increases soil conservation through greater ground cover than sole cropping.

\subsubsection{The grain phosphorus content}

Grain phosphorus content increased as nitrogen fertilization levels increased and under intercropping system compared to mono-cropping system during both seasons. It varied from 0.40 to $0.54 \%$ when nitrogen fertilization increased from 90 to $150 \mathrm{~kg} \mathrm{~N} /$ fed under intercropping system and it differed from 0.37 to $0.46 \%$ for the corresponding treatments under mono-cropping system in the $1^{\text {st }}$ season. The same trend was realized in the $2^{\text {nd }}$ season since the grain phosphorus content increased from 0.59 to $0.78 \%$ and from 0.46 to $0.74 \%$ under inter and mono-cropping system, respectively for the corresponding treatments in the $2^{\text {nd }}$ season. On average basis, the grain phosphorus content 
increased by 11.75 and $13.79 \%$ in the $1^{\text {st }}$ and $2^{\text {nd }}$ season, respectively (Table 3 ). The high phosphorus content of maize seed under $\mathrm{N}$-fertilizer treated plots may have been attributed to increased uptake of $\mathrm{N}$ by maize. Molaaldoila et al. (2017) stated that among different intercrops, cowpea noted maximum uptake of nitrogen $\left(68 \mathrm{~kg} \mathrm{ha}^{-1}\right)$ and phosphorus (2 $\mathrm{kg} \mathrm{ha}^{-1}$ ) followed by soybean with 60 and $2 \mathrm{~kg} \mathrm{ha}^{-1} \mathrm{NP}$, separately.

\subsubsection{The grain potassium content}

Grain potassium content increased as nitrogen fertilization levels increased and under intercropping system compared to mono-cropping system during both seasons. It varied from 0.62 to $0.74 \%$ when nitrogen fertilization increased from 90, 120 and $150 \mathrm{~kg} \mathrm{~N} /$ fed under intercropping system and it differed from 0.56 to $0.67 \%$ for the corresponding treatments under mono-cropping system in the $1^{\text {st }}$ season. The same trend was realized in the $2^{\text {nd }}$ season since the grain potassium content increased from 0.72 to $0.84 \%$ and from 0.66 to $0.75 \%$ under inter and mono-cropping system, respectively for the corresponding treatments in the $2^{\text {nd }}$ season. On average basis, the grain potassium content increased by 8.13 and $9.85 \%$ in the $1^{\text {st }}$ and $2^{\text {nd }}$ season, respectively (table 3 ). The higher potassium content under intercropping system agreed with those results obtained by Chalka and Nepalia (2006) whom found that maize-cowpea intercropping increase the amount of nitrogen, phosphorus and potassium contents compared to mono-crops of maize. Wiebold and Scharf (2006) mentioned that potassium regulate stoma closure that prevent water wasting, regulating osmosis, increase water use efficiency and improved growth condition of corn plants. Dahmardeh et al. (2010) reported that maize-cowpea intercropping increases the amount of NPK contents compared to mono-crops of maize. Belel et al. (2014) revealed that uptake of nitrogen, phosphorus, potassium by maize was found to reduced significantly due to intercropping (263, 13 and 138 NPK kg /ha) as against sole cropping (305, 16 and 188 NPK Kg /ha).

\subsection{Maize water relationship}

Actual evapotranspiration $\left(\mathrm{ET}_{\mathrm{a}}\right)$ of maize plants as affected by nitrogen levels under intercropping system through 2017 and 2018 growing season is presented in Table (4). The data showed that $\mathrm{ET}_{\mathrm{a}}$ values increased as nitrogen level increased and with intercropping compared to mono-cropping system. In general, the $\mathrm{ET}_{\mathrm{a}}$ values were higher in the $2^{\text {nd }}$ season than that in the $1^{\text {st }}$ season. The $\mathrm{ET}_{\mathrm{a}}$ values were $2381.96,2414.72$ and $2433.97 \mathrm{~m}^{3}$ /fed at 90,120 and 150 $\mathrm{kg} \mathrm{N} / \mathrm{fed}$, respectively in the $1^{\text {st }}$ season under intercropping system. They were 2334.50, 2369.92 and $2389.24 \mathrm{~m}^{3} / \mathrm{fed}$ under mono-cropping system for the corresponding treatments. The same trend was realized in the $2^{\text {nd }}$ season since 
the $\mathrm{ET}_{\mathrm{a}}$ values were $2635.64,2671.90$ and $2702.98 \mathrm{~m}^{3} / \mathrm{fed}$ under intercropping system and they were $2587.48,2634.80$ and $2661.26 \mathrm{~m}^{3} / \mathrm{fed}$. under monocropping system for the corresponding treatments. On average basis, the $\mathrm{ET}_{\mathrm{a}}$ value was increased by 1.93 and $1.61 \%$ in the $1^{\text {st }}$ and $2^{\text {nd }}$ season, respectively (Table 4). The crop water productivity (CWP) data in Table (4) and Figure (1) showed the effect of nitrogen levels under mono and intercropping system through 2017 and 2018 growing season. In general, the CWP increased as nitrogen level increased and under intercropping system compared to monocropping system during both seasons. The CWP was $1.15,1.33$ and $1.49 \mathrm{~kg} / \mathrm{m}^{3}$ for 90,120 and $150 \mathrm{~kg} \mathrm{~N} / \mathrm{fed}$, respectively under intercropping system in the $1^{\text {st }}$ season. They were $0.97,1.12$ and 1.23 under mono-cropping system for the corresponding treatments in the $1^{\text {st }}$ season. The CWP values were $1.18,1.28$ and $1.40 \mathrm{~kg} / \mathrm{m}^{3}$ for 90,120 and $150 \mathrm{~kg} \mathrm{~N}$ /fed, respectively under intercropping system in the $2^{\text {nd }}$ season. They were 1.0 , 1.07 and $1.18 \mathrm{~kg} / \mathrm{m}^{3}$ under monocropping system for the corresponding treatments in the $2^{\text {nd }}$ season. On average basis, the CWP value was increased by 19.15 and $18.55 \%$ in the $1^{\text {st }}$ and $2^{\text {nd }}$ season, respectively (Table 4). These results are in agreement of those obtained by Tsubo et al. (2005) whom showed that maize-legume combination registered greater water use efficiency than that of sole crops and under water stress conditions. Improvements in WUE could have been attributed to increase in yield in response to fertilizer application. Improving soil fertility improves water use by increasing photosynthetic capacity of the leaf through improved enzyme function and enhanced carbon dioxide assimilation (Deng et al., 2006).

Table (4): The effect of nitrogen fertilization levels on maize water relationship under both solely and intercropping system during the growing seasons of 2017 and 2018.

\begin{tabular}{|c|c|c|c|c|c|c|c|c|c|}
\hline \multirow{3}{*}{$\begin{array}{l}\text { Maize yield and } \\
\text { quality }\end{array}$} & \multirow{3}{*}{$\begin{array}{l}\text { Cultivation } \\
\text { system }\end{array}$} & \multicolumn{8}{|c|}{ Nitrogen (kg /fed) } \\
\hline & & \multicolumn{4}{|c|}{2017} & \multicolumn{4}{|c|}{2018} \\
\hline & & 90 & 120 & 150 & Average & 90 & 120 & 150 & Average \\
\hline \multirow{3}{*}{ Maize Eta $\left(\mathrm{m}^{3} / \mathrm{fed}\right)$} & Inter. & 2381.96 & 2414.72 & 2433.97 & 2410.22 & 2635.64 & 2671.90 & 2702.98 & 2670.17 \\
\hline & Sole & 2334.50 & 2369.92 & 2389.24 & 2364.55 & 2587.48 & 2634.80 & 2661.26 & 2627.85 \\
\hline & R.C. & 2.03 & 1.89 & 1.87 & 1.93 & 1.86 & 1.41 & 1.57 & 1.61 \\
\hline \multirow{3}{*}{ C W P $\left(\mathrm{kg} / \mathrm{m}^{3}\right)$} & Inter. & 1.15 & 1.33 & 1.49 & 1.32 & 1.18 & 1.28 & 1.40 & 1.29 \\
\hline & $\begin{array}{l}\text { Sole } \\
\end{array}$ & 0.97 & 1.12 & 1.23 & 1.11 & 1.00 & 1.07 & 1.18 & 1.09 \\
\hline & R.C. & 18.27 & 18.50 & 20.68 & 19.15 & 17.43 & 19.17 & 19.03 & 18.55 \\
\hline \multirow{3}{*}{ L.E.R. } & Maize & 1.04 & 1.03 & 1.04 & 1.04 & 1.04 & 1.03 & 1.05 & 1.04 \\
\hline & Green bean & 0.32 & 0.38 & 0.44 & 0.38 & 0.32 & 0.38 & 0.44 & 0.38 \\
\hline & Total L.E.R. & 1.36 & 1.41 & 1.48 & 1.42 & 1.36 & 1.41 & 1.49 & 1.42 \\
\hline L.S. (\%) & Inter. & 26.37 & 29.18 & 32.64 & 29.40 & 26.57 & 29.39 & 32.68 & 29.55 \\
\hline \multirow{2}{*}{\multicolumn{2}{|c|}{ Maize yield and quality }} & \multicolumn{2}{|c|}{ Maize $\mathrm{ET}_{\mathrm{a}}$} & \multicolumn{2}{|c|}{ CW P } & \multicolumn{2}{|c|}{ L.E.R. } & \multicolumn{2}{|c|}{ L.S. (\%) } \\
\hline & & 2017 & 2018 & 2017 & 2018 & 2017 & 2018 & 2017 & 2018 \\
\hline \multirow{3}{*}{$\operatorname{LSD}_{(0.05)}$} & Inter. & 0.02 & 0.04 & 0.04 & 0.04 & 0.02 & 0.03 & 0.08 & 0.02 \\
\hline & $\mathrm{N}$ & 0.03 & 0.03 & 0.03 & 0.03 & 0.02 & 0.02 & NS & 0.04 \\
\hline & Inter. X N & NS & NS & NS & 0.05 & NS & NS & NS & NS \\
\hline
\end{tabular}

Inter. = Intercropping, R.C. = Relative change, $\mathrm{N}=$ Nitrogen fertilizer levels $(\mathrm{kg} \mathrm{N} / \mathrm{fed}), \mathrm{L} . E . R .=$ Land equivalent ratio, CWP = Crop water productivity, L.S. = Land Saved. 


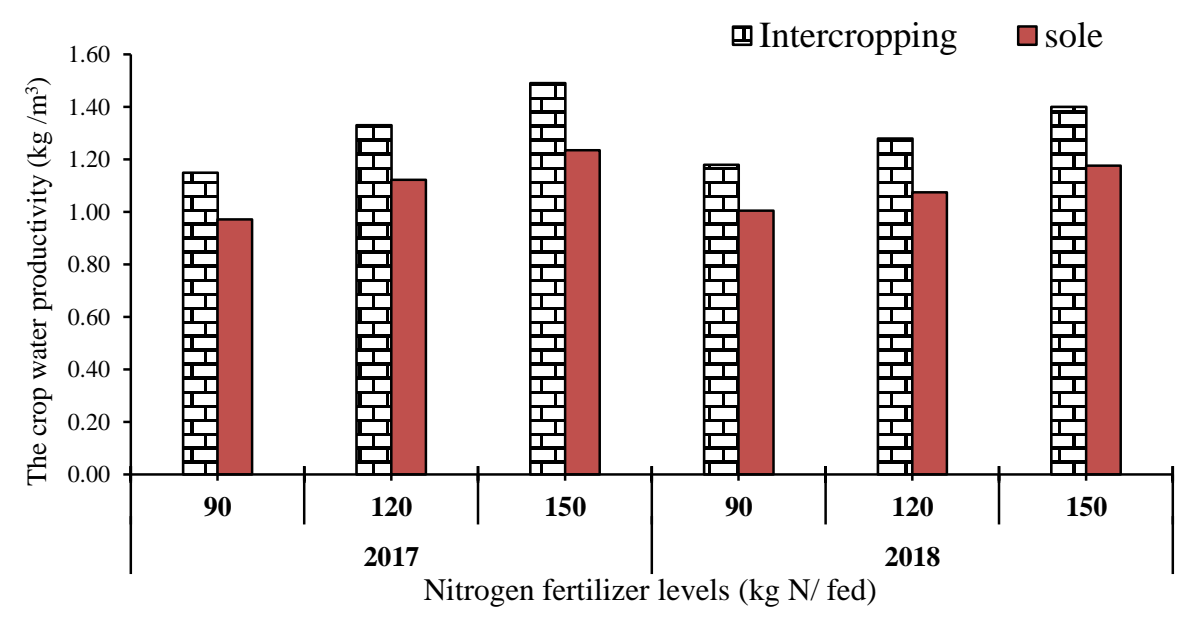

Figure (1): The effect of nitrogen fertilization levels on crop water productivity under both solely and intercropping system during the growing seasons of 2017 and 2018.

\subsection{Intercropping efficiency}

Land equivalent ratio (LER) is the most common index adopted in intercropping to measure the land productivity. Therefore it shows the intercropping efficiency for using the environmental resources compared to mono-cropping. Land equivalent ratio (LER) indicates relative land area under sole crop required to produce the same yield as obtained under intercropping system at the same level of management (Brintha and Seran, 2009). In both growing seasons, the maximum value of partial LER (1.05) was recorded when maize fertilized by $150 \mathrm{~kg} \mathrm{~N} /$ fed (Table 4) and Figure (2). Whereas the lowest one (1.03) was obtained when maize plants fertilized by $120 \mathrm{~kg} \mathrm{~N} / \mathrm{fed}$. The same trend was recorded under green bean, where the highest partial LER value (0.44) was recorded when fertilized by
$150 \mathrm{~kg} \mathrm{~N} / \mathrm{fed}$. Whereas the lowest one (0.32) was obtained for green bean fertilized by $90 \mathrm{~kg} \mathrm{~N} / \mathrm{fed}$. The reduction of partial LER values of green bean crop was greater than obtained from maize crop. This result attributed to increase reduction of green bean crop than maize crop. The total LER values were 1.36, 1.41 and 1.48 for 90,120 and $150 \mathrm{~kg} \mathrm{~N}$ /fed, respectively in the both seasons Table (4) and Figure (2). The LER 1.48 suggests that there is $48 \%$ greater land area requirement for the monoculture system or $48 \%$ greater relative yield for intercropping of maize with green bean and/or $48 \%$ greater biological efficiency for intercropping these two crops. In both seasons, the total LER under nitrogen treatments were greater than one, indicating that all treatments had an advantage in land use. These results are in agreement with those obtained by Jiao et al. (2008) whom noted that maize and 
legumes are morphologically dissimilar and their time of peak demand and requirement of light, nutrients and water are different. Therefore, complementary effect between component crops is very common. Maize used strong light and groundnut preferred weak light (because maize provided partial shade) in maizegroundnut intercropping system and the system registered yield advantage. Hirpa (2014) stated that intercropping system recorded the total LER values ranged from 1.21 to $1.41 \mathrm{in} 2013$ and from 1.18 to 1.40 in 2014. This means that higher productivity per unit area was yielded by growing maize and soybean crops together than by growing them sole. The LER indicates the advantage of an intercropping with efficient resource utilization compared to pure stands of respective crops. The value of LER greater than unity (1.0) is indicative of the advantages in intercropping system. The LER indicates on efficiency of using land area, but time factor is not considered for which the crop occupies the land area. To rectify the limitation of the LER, the concept of area time equivalent ratio (ATER) has been developed considering the occupancy of land by the crops for certain periods (Maitra et al., 2019).

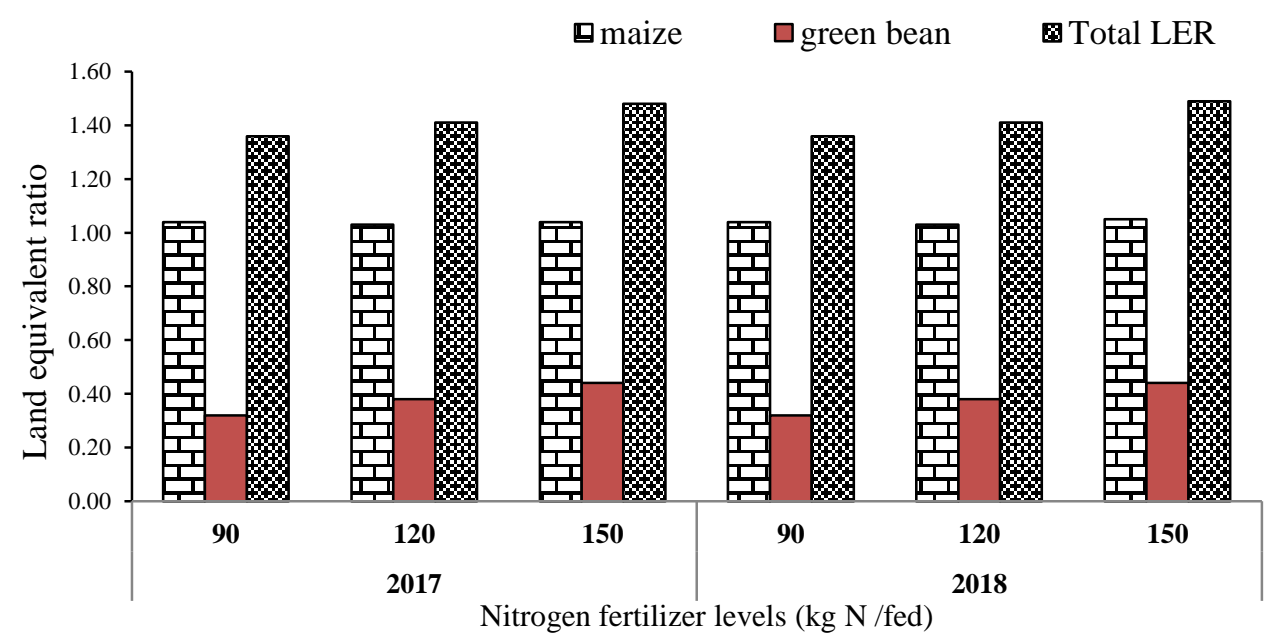

Figure (2): The effect of nitrogen fertilization levels on land equivalent ratio under both solely and intercropping system during the growing seasons of 2017 and 2018.

Land saved calculations was another index used to assess the advantage of the intercropping efficiency. It indicates the amount of land saved from intercropping that could be used for other agricultural purposes. The saved land as affected by nitrogen fertilization levels and intercropping maize with green bean is shown in table (4). In general, nitrogen fertilization levels realized positive 
effects on the saved land. On average basis, the saved land was 26.37, 29.18 and $32.64 \%$ for 90,120 and $150 \mathrm{~kg}$ $\mathrm{N} /$ fed., respectively under intercropping system in the $1^{\text {st }}$ season. They were $26.57,29.39$ and 32.68 for the corresponding treatments in the $2^{\text {nd }}$ season. These results are in agreement with those obtained by Li et al. (2020) whom revealed that both the low- and high-yield intercropping strategies saved $16-29 \%$ of the land and $19-36 \%$ of the fertilizer compared with monocultures grown under the same management as the intercrop. Also, they found that the land savings in intercrops with maize were $13 \%$ larger than in intercrops without maize. Nassary et al. (2020) concluded that the land equivalent ratios (LERs) of intercrops between maize and common bean showed that the saved lands were 48 and $55 \%$, which would have been required as additional land for monoculture of each crop (maize or common bean) if not intercropped.

\section{Conclusion}

It could be concluded that the maximum maize yield (grain and straw) and its component (plant height, stem diameter, leaves number/plant, grains number/cob and weight of 1000 grains) as well as NPK content in maize grain were observed in intercropping maize with green bean received $150 \mathrm{~kg} \mathrm{~N} / \mathrm{fed}$. The maximum value of partial land equivalent ratio (LER) of maize or green bean was recorded when they fertilized by $150 \mathrm{~kg}$ N/fed. The LER 1.48 suggests that there is $48 \%$ greater land area requirement for the monoculture system or $48 \%$ greater relative yield for intercropping of maize with green bean and/or $48 \%$ greater biological efficiency for intercropping of these two crops. The LERs of intercrops between maize and green bean showed that the saved lands were over $36 \%$ which would have been required as additional land for monoculture of each crop (maize or green bean) if not intercropped. The total LER under fertilization treatments were greater than one, indicating that all treatments had an advantage in land use. The highest values of crop water productivity of $1.40 \mathrm{~kg} / \mathrm{m}^{3}$ under intercropping system and $1.18 \mathrm{~kg} / \mathrm{m}^{3}$ under mono-cropping system were recorded with $150 \mathrm{~kg} \mathrm{~N} / \mathrm{fed}$. In general, fertilization level of $150 \mathrm{~kg} \mathrm{~N} /$ fed. proved to be the most effective treatment on maize grain yield and its component as well as maize water relationships especially crop water productivity.

\section{References}

Adesoji, A. G., Abubakar, I. U., Tanimu, B. and Labe, D. A. (2013), "Influence of incorporated short duration legume fallow and nitrogen on maize (Zea mays L.)", AmericanEurasian Journal Agriculture \& Environ Sciences, Vol. 13 No. 1, pp. 58-67.

Adu-Gyamfi, J. J., Myaka, F. A., Sakala, W. D., Odgaard, R., Vesterager, J. 
M. and Jensen, H. H. (2007), "Biological nitrogen fixation and nitrogen and phosphorus budgets in farmer- managed intercrops of maize-pigeonpea in semi-arid southern and eastern Africa", Plant \& Soil, Vol. 95 No. (1-2), pp. 127136.

Akunda, E. M. (2004), "Improving Food production by understanding the effects of intercropping and plant population on soybean nitrogen fixing attributes", Journal of Food Technology in Africa, Vol. 6 No. 4, pp. 110-115.

Ali, N. and Anjum, M. M. (2017), "Effect of different nitrogen rates on growth, yield and quality of maize", Middle East Journal of Agriculture, Vol. 1, pp. 107-112.

Almaz, M. G., Halim, R. A. and Martini, M. Y. (2017), "Effect of combined application of poultry manure and inorganic fertiliser on yield and yield components of maize intercropped with soybean", Pertanika Journal of Tropical Agricultural Science, Vol. 40 No. 1, pp.173-184.

Ananthi, T., Amanullah, M. M. and AlTawaha, A. R. M. S. (2017), "A review on maize-legume intercropping for enhancing the productivity and soil fertility for sustainable agriculture in India", Advances in Environmental Biology, Vol. 11 No. 5, pp. 49-63.

Belel, M. D., Halim, R. A., Rafii, M. Y. and Saud, H. M. (2014), "Intercropping of corn with some selected legumes for improved forage production: A Review", Journal of Agricultural Science, Vol. 6, No. 3, pp. 48-62.

Brintha, I. and Seran, T. H. (2009), "Effect of paired row planting of radish (Raphanus sativus L.) intercropped with vegetable amaranthus (Amaranthus tricolor L.) on yield components of Radish in sandy regosol", Journal Agriculture Science, Vol. 4, pp.19-28.

Carpici, E. B., Celik, N. and Bayram, G. (2010), "The effects of salt stress on the growth, biochemical parameterand mineral element content of some maize (Zea mays L.) cultivars", African Journal of Biotechnology, Vol. 9 No. 41, pp. 6937-6942.

Chalka, M. K. and Nepalia, V. (2006), "Nutrient uptake appraisal of maize intercropped with legumes and associated weeds under the influenced of weed control", Indian Journal of Agricultural Research, Vol. 40 No. 2, pp. 86-91.

CiampittiI, A., and Vyn, T. J. (2010), "A comprehensive study of plant density consequences on nitrogen uptake dynamics of maize plants from vegetative to reproductive stages", Field Crops Research, Vol. 121 No. 1, pp. 2-18.

Coll, L., Cerrudo, A., Rizzalli, R., Monzon, J. P. and Andrade, F. H. 
(2012), "Capture and use of water and radiation in summer intercrops in the south-east Pampas of Argentina", Field Crops Research, Vol. 134, pp. 105-113.

Dahmardeh, M., Ghanbari, A., Syahsar, B. A. and Ramrodi, M. (2010), "The role of intercropping maize (Zea mays L.) and cowpea (Vigna unguiculata L.) on yield and soil chemical properties", African Journal of Agricultural Research, Vol. 5 No. 8, pp. 631-636.

Deng, X., Shan, L., Zhang, H. and Turner, N. C. (2006), "Improving agricultural water use efficiency in arid and semiarid areas of China", Agricultural Water Management, Vol. 80, pp. 23-40.

Dps, B., Simran, S., Kaur, V. S. and Kaushal S. (2019), "Role of nitrogenous fertilizer in maize: A review", Journal of Pharmacognosy and Phytochemistry, Vol. 8 No. 3, pp. 3797-3800.

F.A.O. (1980), Soil and plant testing as a basis of fertilizer recommendations, FAO Soils, Bulletin No.38/2, Rome, Italy.

Fathi, V., Ramezanpour, S., Balalaie, S., Rominger, F. and Bijanzadeh H. R. (2014), "An efficient approach to the synthesis of hydrazinyl pseudo peptides", Helvetica Chimica Acta, Vol. 97 No 12, pp. 1630-1637.

Gadallah, R. A. and Gabra, A. M. (2015), "Effect of intercropping patterns and nitrogen fertilization levels on yield and yield components of maize and soybean", Annals of Agricultural Science, Moshtohor, Vol. 53 No. 2, pp. 187-197.

Heidari, H., Nassiri, B. M., Noorbakhshia, S. J. and Kachoie, M. A. (2015), "An evaluation of the yield of corn (Zea mays L.) and bean (Phaseolus vulgaris) intercrop", Academie Royale Des Sciences D Outre-Mer Bulletin Des Seances, Vol. 4 No. 2, pp.132-135.

Hirpa, T. (2014), "Response of maize crop to spatial arrangement and staggered interseeding of haricot bean", International Journal of Environment, Vol. 3, pp. 126-138.

Ijoyah, M. O. and Fanen, F. T. (2012),"Effects of different cropping pattern on performance of maizesoybean mixture in Makurdi, Nigeria", Journal Crop Science, Vol.1 No. 2, pp. 39-47.

Ijoyah, M. O. and Jimba, J. (2012), "Evaluation of yield and yield components of maize (Zea mays L.) and okra (Abelmoschus esculentus L. Moench) intercropping system at Makurdi, Nigeria", Journal of Biodiversity and Environmental Sciences, Vol. 2 No. 2, pp. 38-44.

Imran, S., Arif, M., Khan, A., Khan, M. A. and Latif, A. (2015), "Effect of nitrogen levels and plant population on yield and yield components of maize", Advances in Crop Science and Technology, Vol. 3, pp. 170. 
Israelson, O. W. and Hansen, $\mathrm{V}$.E. (1962), Irrigation Principals and Practice, $3^{\text {rd }}$ Ed., John Wiley and Sons International Edition, New York, USA.

JIao, N. Y., Zhao, C., Ning, T. Y., Hou, L. T., FU, G. Z., Li, Z. J. and Chen, M. C. (2008), "Effects of maizepeanut intercropping on economic yield and light response of photosynthesis", Chinese Journal of Applied Ecology, Vol. 19, pp. 981985.

Kaur, A. (2016), Effect of different planting methods and nitrogen levels on the growth, yield and quality of Kharif maize, M.Sc. Thesis, Department of Agronomy, Punjab Agricultural University Ludhiana, Punjab, India.

Kaur, J. and Vashisht, K. K. (2015), "Influence of Nitrogen levels, irrigation regimes and planting methods on growth attributes and yield of spring maize", Agricultural Research Journal, Vol. 65 No. 1, pp. 13-18.

Klute, A. (1986), Methods of Soil analysis, Part 1, Physical and Mineralogical Properties, $2^{\text {nd }}$ Ed., American Society of Agronomy, Madison, Wisconsin, USA.

Kumar, A. (2008), "Growth, yield and water use efficiency of different maize (Zea mays L.) based cropping systems under varying planting methods and irrigation levels", Indian Journal Agricultural Science,
Vol. 78, pp. 254-57.

Latati, M., Bargaz, A., Belarbi, B., Lazali, M., Benlahrech, S., Tellah, S., Kaci, G., Drevon, J. J. and Ounane, S. M. (2016), "The intercropping common bean with maize improves the rhizobial efficiency, resource use and grain yield under low phosphorus availability", European Journal Agronomy, Vol. 72, pp. 80-90.

Leila, H. and Soleymani, A. (2014), "Effect of different amounts of nitrogen fertilizer on grain yield of forage corn cultivars in Isfahan", International journal of Advanced Biological and Biomedical Research, Vol. 2 No. 3, pp. 608614.

Li, C., Hoffland, E., Kuyper, T. W., Yu, Y., Zhang, C., Li, H., Zhang, F. and van der Werf, W. (2020), "Syndromes of production in intercropping impact yield gains", Nature Plants, Vol. 6, pp. 653-660.

Maitra, S., Palai, J., Manasa, B. P. and Kumar, D. P. (2019), "Potential of intercropping system in sustaining crop productivity", International Journal of Agriculture, Environment and Biotechnology, Vol. 12 No. 1, pp. 39-45.

Mateusso, J. M. M., Mugwe, J. N. and Muna, M. (2014), "Effects of different maize (Zea Mays L.) soybean (Glycine max (L.) Merrill) intercropping patterns on yields and its economics", Academia Journal of 
Agriculture Research, Vol. 2, pp. 159-166.

Mead, R. and Riley, J. (1981), "A review of statistical ideas relevant to intercropping research", Journal of the Royal Statistical Society, Vol. 144 No. 4, pp. 462-487.

Molaaldoila, Y. A. A., Al-Mosanif, E. M., Al-Aqil, M. M. and Al-Kumali, A. H. A. (2017), "Effect of nitrogen levels on yield, competitive, economic indices and efficiency of sorghum cultivars and common bean intercropping", Agricultural Research \& Technology, Vol. 3 No. 3: 555614.

Moriri, S., Owoeye, L. G. and Mariga, I. K. (2010), "Influence of component crop densities and planting patterns on maize production in dry land maize/cowpea intercropping system", African Journal of Agricultural Research, Vol. 5 No. 11, pp. 1200-1207.

Nassary, E. K., Baijukyab, F. and Ndakidemi, P. A. (2020), "Productivity of intercropping with maize and common bean over five cropping seasons on smallholder farms of Tanzania", European Journal of Agronomy, Vol. 113, 125964.

Nissen, O. (1989), MSTAT-C. A microcomputer program for the design, management and analysis of agronomic research experiments, Michigan State University East Lansing, Michigan, USA, Vol. 2, pp.
$132-135$.

Nyasasi, B. T. and Kisetu, E. (2014), "Determination of land productivity under maize-cowpea intercropping system in agro-ecological zone of Mount Uluguru in Morogoro Tanzani", Global Journal Agriculture Science, Vol. 2 No. 2, pp.147-157.

Page, A. L., Miller, R. H. and Keeney, D. R. (1982), Methods of Soil Analysis, $2^{\text {nd }}$ Ed., American Society of Agronomy, Madison, WI., USA.

Sabiel, S. A. I. and Abdelmula, A. A. (2007), Genotypic and differential responses of growth and yield of some maize (Zea mays L.) genotypes to drought stress, Tropentag 2007; Conference on International Agricultural Research for Development, University of KasselWitzenhausen and University of Göttingen, Germany,

Sadeghi, H and Kazemeini, S. A. (2012), "Interaction between different nitrogen fertilizer levels and maizebean intercropping patterns", Journal of Ecology and Environment, Vol. 35 No. 4, pp. 269-277.

Saleem, R., Ahmed, Z. I., Ashraf, M., Arif, M., Azimmalik, M., Munir, M. and Azeemkhan, M. (2011), "Response of maize-legume intercropping system to different fertility sources under rainfed conditions", Sarhad Journal Agricultural, Vol. 27 No. 4, pp. 
504-511.

Sebetha, E. T., Modi1, A. T. and Owoeye, L. G. (2015), "Cowpea crude protein as affected by cropping system, site and nitrogen fertilization", Journal of Agricultural Science, Vol. 7 No. 1, pp. 224-234.

Shrestha, J., Chaudhary, A. and Pokhrel, D. (2018), "Studied the application of nitrogen fertilizer in maize in Southern Asia: A review", Peruvian Journal of Agronomy, Vol. 2 No 2, pp. 22-26.

Singh, D. K. and Agrawal, R. L. (2004), "Nitrogen and phosphorus nutrition of pearl millet (Pennisetum glaucum) grown in sole and intercropping systems under rainfed conditions", Indian Journal of Agronomy, Vol. 49 No. 3, pp. 151153.

Thayamini, H. S. and Karunarathna, B. (2010), "Review on Maize Based Intercropping", Journal of Agronomy, Vol. 9 No. 3, pp. 135145.

Thomas, R. L., Sheard, R. W. and Moyer, J. R. (1967), "Comparison of conventional and automated procedures for nitrogen, phosphorus, and potassium analysis of plant materials using a single digest", Agronomy Journal, Vol. 59, pp. 240-243.

Tsubo, M., Walker, S. and Ogindo, H. O. (2005), "A simulation model of cereal-legume intercropping system for semi-arid regions", Field crops Research, Vol. 93 No. 1, pp.10-22.

Vites, F. G. (1965), Increasing water use efficiency by soil management, America Society Agronomy, Madison, Wisconsin, pp. 259-274.

Widowati, W. H. U., Guritno, B. and Soehono, L. A. (2012), "The effect of biochar on the growth and $\mathrm{N}$ fertilizer requirement of Maize (Zea mays L.) in green house experiment", Journal of Agricultural Science Archives, Vol. 4 No. 5, pp. e25.

Wiebold, B. and Scharf, P. (2006), "Potassium deficiency symptoms in drought stressed crops, plant stress resistance and the impact of potassium application south china", Agronomy Journal, Vol. 98, pp. 1354-1359.

Willey, R. W. (1985), "Evaluation and presentation of intercropping advantages", Exp. Agric, Vol 21, pp. 119-133.

Woldesenbet, M. and Haileyesus, A. (2016), "Effect of nitrogen fertilizer on growth yield and yield components of Maize (Zea Mays L.) Decha district, Southwestern Ethiopia", International Journal of Research - Granthaalayah, Vol. 4 No. 2, pp. 95-100.

Zulfiqar, U., Ishfaq, M., Yasin, M. U., Ali, N. M., Ullah, A. and Hameed, W. (2017), "Performance of maize 
yield and quality under different irrigation regimes and nitrogen levels", Journal Global Innoveronment Agriculture Society Science, Vol. 5 No. 4, pp. 59-164. 